\title{
Motives for Entrepreneurship: The Case of Lebanese Family Businesses
}

\author{
Josiane Fahed-Sreih ${ }^{1}$ and David Pistrui 2,3 \\ ${ }^{1}$ Department of Business Studies School of Business, \\ Lebanese American University Byblos, Lebanon, \\ ${ }^{2}$ Acumen Dynamics, LLC, Chicago, \\ ${ }^{3}$ Austrian Economics Center Vienna, \\ 1,2 USA \\ ${ }^{3}$ Austria
}

\section{Introduction}

\subsection{Overview}

Family businesses are the engine that drives socioeconomic development and wealth creation around the world, and entrepreneurship is a key driver of family businesses. The ability to build and keep the business running over generations is a major element of family business continuity and is influential in strategic execution, innovation, and growth. Entrepreneurial family businesses are a primary source of job creation (Shanker \& Astrachan, 1996) in market economies where resources are allocated via supply and demand. In Lebanon, family businesses constitute $85 \%$ of the private sector, accounting for 1.05 million of 1.24 million jobs (Fahed-Sreih, 2006). The family unit is usually the only intact institution capable of sustaining entrepreneurial activities in Lebanon following civil war.

Lebanon provides a unique experiment where to explore entrepreneurship, family business, and SME development. Lebanese firms went through years of war and survived the massive destruction. Given the instability in the country in recent decades, it comes as no surprise that Lebanon has low scores when it comes to economic performance. Accordingly, researchers have a chance to spot, survey, and analyze the personality of new Lebanese entrepreneurs, the enterprises they are building, and family network involvement.

The general research question posed is: "What are the characteristics attributes, and growth orientations of Lebanese entrepreneurs and what relationships, roles, and contributions do family and culture play in the development of private SMEs?"

This study explores four dimensions shaping entrepreneurial characteristics and orientations: (a) the psychographic motives and demographic attributes of the entrepreneur, (b) the types of businesses being started, as well as their ownership structure and method of 
establishment, (c) family and enterprise relationships related to participation and influence including employment, investment, and advice, and (d) how family participation shapes and influences the growth intentions and expansion plans of Lebanese entrepreneurs.

By understanding how social forces affect entrepreneurial motives, we expect to find how culture influences and helps in starting a private enterprise. This study explores demographic aspects (age, education and experience), and how they help in starting a new business.

\section{Entrepreneurship in a shaky economy}

Since ancient times, Lebanese then called Phoenicians; Lebanon was the center of commerce In the Middle east region. The country was famous for its marketing skills and its educated inhabitants. Before the 1970s, Lebanon's per capita income was similar to that of Southern Europe (Plamodon, 2004). This created a sophisticated consumer base, particularly in and around Beirut, Lebanon's capital.

Twenty years of civil war damaged Lebanon's infrastructure and cut its GNP output by half. After the war ended in 1991, Lebanon main source of income was tourism and banking. Following the September 11, 2001 attacks, Lebanon was seen as the secure place for the Arabs for deposits because of its banking secrecy and was no longer in war. Unfortunately, the assassination of Prime minister Rafic Hariri in February 2005 and afterward bombings major setbacks. Given its security crisis, Lebanon's GDP growth in the first quarter of 2005 was zero (The Daily Star, 2005).

Israeli occupation from 1978 to 2000 and Syrian occupation from 1978 to spring 2005 have left Lebanon with enormous political and financial problems to solve, including physical and social infrastructural reconstruction. The unexpected 34-day Israel-Hizbullah war in July 2006 further distressed the Lebanese economy. The 34 days of fighting killed 1200 Lebanese, destroyed 15,000 homes, and cost the economy approximately twelve billion dollars (The Economist, 2006). The Israeli-Hizbullah conflict caused an estimated \$3.6 billion in infrastructural damage during July and August 2006, and internal Lebanese political tensions continue to hamper economic activity (CIA, 2007). It is within this unstable framework wherein this study was undertaken.

\section{The socioeconomic process of entrepreneurship and the role of the family}

The family plays an important stabilizing role in social and economic value creation and trans generational wealth perpetuation processes (Habbershon \& J. Pistrui, 2002).

Families play an important role during start-up and business development. This study assesses two general areas: 1) what is the direct role of family in the process of developing new venture, and 2) what is the direct role of family in the growth and expansion plans.

Family serves three major functions in its social system. First, it plays an economic role, (Steier, 2003) pointed out the substantial role that familial ties play in the entrepreneurial process, as the family represents a valuable repository of socio-economic resources. Family represents a learning element that teaches and passes on skills that encourage economic development. Secondly, family establishes a moral system, which helps the conduct of the 
unit. Finally, the family creates its own culture, in which family creates a motivating force that is central to private enterprise formation and enterprise preservation across successive generations.

\section{Where are we from growth orientation, entrepreneurship, and family participation?}

Dunkelberg and Cooper (1982) argue that growth orientation in and of itself represent an important entrepreneurial characteristic. Carland et al. (1984) suggest that planned growth is an important method of differentiating entrepreneurs from small business owners. This research intends to build on the work of Pistrui et al., (1997), Gundry and Welsch (2001), and Pistrui (2002) by advancing the understanding of how family participation and involvement affect growth orientations and expansion plans of Lebanese entrepreneurially led enterprises.

\section{Lebanese culture, family dynamics, and business development}

It is known in Lebanon and in the Arab world, that family business is a way to improve a family's social standing (Fahed-Sreih, 2006, p.206). This special way of managing a business in Arab countries relates to the socioeconomic and cultural backgrounds of these families (Ali, 1993).

Usually succession is not openly discussed, older generation tend to keep in management, and refuse to give the power as long as they can stay in business. Lebanese family firms tend to exhibit perseverance, follow a path of self-reliance, and, despite the turmoil of war and destruction, express optimism (Fahed-Sreih, 2006).

sually it is difficult for researches to collect data in developed countries with transitional economy. Having survived harsh wars, occupation and ongoing uncertainty, Lebanese firms are unenthusiastic to fill surveys. Besides, most enterprises are very cautious in sharing details of their companies. To overcome these obstacles, personal interviews were required.

Drawing from the database of registered and active Lebanese entrepreneurially led enterprises on file with the Lebanese American University's Institute for Family and Entrepreneurial Business, a series of 112 in-depth personal interviews was conducted over a twelve-month period between May 2006-07. The interviews took place at the business premises with the founder, president, or CEO. Interviewees were assured of complete confidentiality.

The Entrepreneurial Profile Questionnaire (EPQ) was utilized as a data collection instrument. The EPQ was designed to survey the effect of individual, societal, and environmental factors on entrepreneurship and family business development by collecting a combination of demographic information and extensive detail related to characteristics and orientations. The EPQ was successfully piloted and validated through a series of studies in Romania (Pistrui, 2002, Pistrui et al., 1997), Germany (Pistrui et al., 2003, Wintermantel, 1999), Venezuela (Pistrui et al., 1999), South Africa (Welsch et al., 1996), the United States (Gundry et al., 2001, ), and China (Pistrui et al., 2006). The EPQ has been independently validated as a valuable data collection tool in transition economies such as post-communist Eastern and Central Europe. 


\section{Lebanese entrepreneurial motives}

In Table 1, the mean ratings of the top ten motive-based attributes were arranged in descending order, including the standard deviations. Given the fact that the attributes are not independent, a standard T-test of means was used to determine whether the overall mean ratings were different. Results verify that the attributes differ significantly in importance. The results suggest that Lebanese entrepreneurs are motivated by the need for independence and personal flexibility, family well-being, and the desire for high-income levels. Family security and family life also appear to be central motivating forces.

\begin{tabular}{lll}
\hline Item & Mean & $(S D)$ \\
\hline 1. To be my own boss, to work for myself. & 3.93 & $(.945)^{* * *}$ \\
2. To make better use of my training or skills. & 3.89 & $(.902)^{* * *}$ \\
3. To give myself, my husband/ wife and children security. & 3.87 & $(.973)^{* * *}$ \\
4. Desire to have high earnings. & 3.87 & $(.893)^{* * *}$ \\
5. To have greater flexibility in my personal and family life. & 3.87 & $(.940)^{* * *}$ \\
6. To achieve something and get recognition for it. & 3.86 & $(.887)^{* * *}$ \\
7. To make a direct contribution to the success of a company. & 3.86 & $(1.036)^{* * *}$ \\
8. To be able to develop an idea for a product or a business. & 3.85 & $(.848)^{* * *}$ \\
9. To control my own time. & 3.85 & $(.859)^{* * *}$ \\
10. To have the opportunity to lead, rather than be led by others. & 3.84 & $(.924)^{* * *}$
\end{tabular}

$\mathrm{N}=112$; Range: $1-5{ }^{* * *} \mathrm{\alpha}=0.001,{ }^{* *} \mathrm{\alpha}=0.01,{ }^{*} \mathrm{\alpha}=0.05$

Source: Family and Cultural Factors impacting Entrepreneurship in war time Lebanon, (Fahed-Sreih et al, 2010)

Table 1. Top Ten Reasons and Motives for Entrepreneurship

Lebanese entrepreneurs are motivated to provide security and to generate the income necessary to create and protect a strong family life. This finding is consistent with the works of Melikian and Diab (1959, 1974), Barakat (1977), Diab (1980), Faour (1998), and Fahed-Sreih (2006), which document the family as the most important social entity among all social institutions in Lebanon. Lebanese entrepreneurs clearly have a unique set of motivational attributes when compared to other transition economies that have suffered socioeconomic turmoil.

\section{Demographic profile: Business and work experience}

Table 2 indicates the profile of our sample. The average age of our sample of Lebanese entrepreneurs is approximately 41 years old. Survey results suggest that entrepreneurship is not an exclusively male activity in Lebanon. Over fifteen percent (16.82\%) of the entrepreneurs surveyed were women, which is similar to findings in China (Pistrui et al., 2006, 2005), Romania (Pistrui et al., 1997), and Hungary (Hisrich \& Fulop, 1997). Furthermore, Fahed-Sreih (2006) points out that although men have historically dominated Lebanese culture, women are entering the work force and starting businesses.

Overall, Lebanese entrepreneurs have a high level of education. The vast majority have a college education, with women having about two years more education than men. It is clear is that Lebanese culture places great value on education and learning. 


\begin{tabular}{lcccccl} 
Category & Total & $\begin{array}{l}\text { Male } \\
\text { Mean }\end{array}$ & (SD) & $\begin{array}{l}\text { Female } \\
\text { Mean }\end{array}$ & (SD) & $\begin{array}{l}\text { Sign. } \\
\text { Diff. }\end{array}$ \\
\hline $\begin{array}{l}\text { Years of } \\
\text { education }\end{array}$ & 16.09 & 15.05 & $(3.56)$ & 17.38 & $(1.82)$ & $0.0264^{*}$ \\
$\begin{array}{l}\text { Years of business } \\
\text { experience }\end{array}$ & 15.51 & 17.17 & $(14.79)$ & 5.80 & $(5.36)$ & $0.0000^{* * *}$ \\
$\begin{array}{l}\text { Years of work } \\
\text { experience }\end{array}$ & 17.22 & 19.31 & $(15.04)$ & 5.88 & $(5.99)$ & $0.0000^{* * *}$ \\
$\begin{array}{l}\text { Age } \\
\text { Total }\end{array}$ & 41.41 & 43.29 & $(14.74)$ & 31.19 & $(8.83)$ & $0.0000^{* * *}$ \\
\hline
\end{tabular}

$\mathrm{N}=112{ }^{* * *} \mathrm{a}=0.001,{ }^{* *} \mathrm{a}=0.01,{ }^{*} \mathrm{a}=0.05$

Source: Family and Cultural Factors impacting Entrepreneurship in war time Lebanon, (Fahed-Sreih et al, 2010)

Table 2. Demographic Profile: Business and Work Experience

Lebanese entrepreneurs have an average of 17 years of work experience. As Table 2 shows, Lebanese entrepreneurs were found to have close to 16 years of business experience (15.51 years on average). Male entrepreneurs have over eleven years more business experience than females. This reflects the fact that it is only within the last decade that Lebanese women have emerged as an active entrepreneurial group. These findings suggest that Lebanon has a deep-rooted entrepreneurial class and an emerging new group of dynamic female entrepreneurs.

\section{Family and enterprise relationships}

The family is at the heart of the Lebanese society. Per Table 3, the family plays an important role in enterprise formation and development. These findings support the studies of FahedSreih (2004), Wellman (2001), Sik et al. (1999), Poutziouris et al. (1997), and Pistrui et al. $(1997,2002,2006)$, which show that the family plays a central role in venture development in transitional economies that have experienced severe socioeconomic turmoil.

Question 1: How many family members are investors in your enterprise?

Question 2: How many family members are full-time employees in your firm?

Question 3: How many family members are part-time employees in your firm?

\begin{tabular}{|c|c|c|c|c|c|c|c|}
\hline Question: & 0 & 1 & 2 & 3 & $4+$ & Mean & (SD) \\
\hline Question 1 & $20 \%$ & $30 \%$ & $19 \%$ & $9 \%$ & $7 \%$ & 1.80 & $(1.60)$ \\
\hline Question 2 & $30 \%$ & $19 \%$ & $25 \%$ & $8 \%$ & $2 \%$ & 3.40 & (14.30) \\
\hline Question 3 & $53 \%$ & $11 \%$ & $18 \%$ & $5 \%$ & $3 \%$ & 0.94 & (1.25) \\
\hline
\end{tabular}

Source: Family and Cultural Factors impacting Entrepreneurship in war time Lebanon, (Fahed-Sreih et al, 2010)

Table 3. Family and Enterprise Relationships - Investment and Employment

Eighty percent of the firms interviewed have one or more family members investing in the business. Further indication of the importance of family involvement in funding start-ups is the fact that $50 \%$ of the firms surveyed have more than one family investor, and $15 \%$ have over four. Family employees are also active in enterprise creation, development, and operation. $70 \%$ of the companies surveyed employ at least one member of the family on a full-time basis. 
Approximately $35 \%$ employ two or more family members on a full-time basis. In contrast, the majority of Lebanese enterprises did not employ family members on a part-time basis.

Employment is seen as a family's obligation. Fahed-Sreih (2006) reported that there was a strong relationship between Lebanese families and their enterprises. Businesses are viewed as an extension of the family.

\section{Type of business organization}

The is $41 \%$ sole proprietorships, $37 \%$ corporations and $20 \%$ limited liability companies (see table 4). These facts indicate that entrepreneurially led SMEs are closely held private enterprises built on family and extended family financial support.

\section{Method of establishment}

Type of Business Organization

\begin{tabular}{ll} 
Registered as: & Percent of Total \\
\hline Sole proprietorship & 41.00 \\
\hline Corporation & 37.10 \\
Limited liability company (LLC) & 20.00 \\
Partnership & 1.90 \\
\hline Total & 100.00 \\
\hline Method of Establishment & \\
Technique & Percent of Total \\
\hline Originate & 52.34 \\
\hline Inherit & 28.04 \\
Purchase & 19.62 \\
\hline Total & 100.00
\end{tabular}

Business Activities of Lebanese Entrepreneurs

Business activities

Percent of Total

1. Construction

24.30

2. Retail

17.76

3. Professional services

15.89

4. Computer/technology

14.02

5. Financial/insurance

11.21

6. Service organization

7.48

7. Transportation

5.61

8. Distribution

2.80

9. Manufacturer

0.93

Total

100.00

$\mathrm{N}=112$

Source: Family and Cultural Factors impacting Entrepreneurship in war time Lebanon, (Fahed-Sreih et al, 2010)

Table 4. Business Organization and Activities of Lebanese Entrepreneurs

Slightly over half $(52.34 \%)$ of the entrepreneurs surveyed originated their enterprises. As Table 4 shows, almost one third of these entrepreneurs $(28.04 \%)$ inherited their business. 
This illustrates the strength of family within the entrepreneurial development of SMEs in Lebanon. Approximately twenty percent of respondents indicated that they purchased their enterprise. It would be interesting to know if they were purchased outright or from family members as part of a succession process.

The findings of this study suggest that Lebanese entrepreneurs are either creating new family enterprises or carrying on the family business as part of a succession process. The results of this study suggest that over $80 \%$ of the entrepreneurs surveyed are leading family businesses. It is evident that there will be an emerging need for succession and continuity assistance as these businesses mature and integrate additional family members into their operations.

\section{Business activities of lebanese entrepreneurs}

Following the post-war economy, the Lebanese entrepreneurs are supervising the rebuilding and development process, filling the voids and gaps, responding to the marketplace demand, and disrupting the geo-political grip imposed by Syrian and Israeli occupation. Three types of business activity, construction $(24.30 \%)$, retail $(17.76 \%)$, and professional services (15.89\%), were found to dominate the sample (see Table 4 ). These three indexes represented well over half $(57.95 \%)$ of those enterprises surveyed.

\section{Family participation, growth Intentions, and expansion plans}

The study focuses on how family participation in employment and financial investment, influence growth intentions and expansion plans of Lebanese entrepreneurs.

\begin{tabular}{lll} 
& Item & Mean $(\mathrm{SD})$ \\
\hline 1. & Adding operating space. & $3.88(1.07)^{* * *}$ \\
2. & Acquiring new equipment. & $3.72(1.01)^{* * *}$ \\
3. & Selling to a new market. & $3.71(1.21)^{* * *}$ \\
4. & Expand current facilities. & $3.68(1.12)^{* * *}$ \\
5. & Expanding distribution channels. & $3.65(1.17)^{* * *}$ \\
6. & Adding specialized employees. & $3.64(1.16)^{* * *}$ \\
7. & Expanding advertising and promotion. & $3.61(1.04)^{* * *}$ \\
8. & Researching new markets. & $3.53(1.05)^{* * *}$ \\
9. & Redesigning layout. & $3.52(1.07)^{* * *}$ \\
10. & Upgrading computer systems. & $3.50(1.05)^{* * *}$ \\
11. & Adding a new product or service. & $3.49(1.23)^{* * *}$ \\
12. & Replace present equipment. & $3.47(1.11)^{* * *}$ \\
13. & Computerizing current operations. & $3.47(1.06)^{* * *}$ \\
14. & Expanding scope of operating activities. & $3.41(1.13)^{* * *}$ \\
15. & Redesigning operating methods. & $3.30(1.14)^{* * *}$ \\
16. & Offsite training for employees. & $3.28(1.20)^{* * *}$ \\
17. & Seeking additional financing. & $3.18(1.22)^{* * *}$ \\
18. & Seeking professional advice. & $3.16(1.18)^{* * *}$ \\
\hline & ${ }^{* * *}$ a $0.001{ }^{* *}$ a $0.01 * a 05$ & $\mathrm{~N}=112$ \\
\hline
\end{tabular}

Source: Family and Cultural Factors impacting Entrepreneurship in war time Lebanon, (Fahed-Sreih et al, 2010)

Table 5. Growth Intentions and Expansion Plans 
The growth model was developed, tested, and confirmed the validity of a growth model based on entrepreneurs' intentions to implement specific attributes associated with market expansion, technological upgrades, and operation/production expansion. Based on this research, we hypothesize that family participation in the business has a positive impact and encourages entrepreneurial growth intentions and expansion plans. Growth intentions and expansion plans were measured along eighteen items as presented in table 5 .

\section{Structural equation modeling}

The research model was tested using covariance-based Structural Equation Modeling (SEM). The evaluation on the measurement model includes an exploratory factor analysis to identify the constructs and examine the convergent and discriminant validity of the research instrument. The evaluation on the structural model consists of estimation of path coefficients and their associated significance p-value. Squared multiple correlations (SMC) are calculated to know the proportion of explained variance in the each construct. Finally, the evaluation of the overall model is on the overall goodness-of-fit for SEM.

SEM is a powerful multivariate technique that facilitates the testing of psychometric properties of the scales used to measure unobserved variables (constructs) as well as estimate the parameters of a structural model, which is the magnitude and direction of the relationship among the model variables (Bollen 1989, Genfen et al. 2000, Hair et al. 1998). SEM embodies two interrelated models. The measurement model represents the relationships between the observed items and their constructs measured by these items, while the structural model represents the paths among a set of dependent and independent variables.

\section{Assessment of the structural model}

The structural model shown in Figure 1 provides the hypothesized relationships between Family Participation (FP) and the growth constructs. As previously discussed, we hypothesized that Lebanese cultural traditions encourage family participation. This in turn has a positive impact on entrepreneurial growth intentions and expansion plans. Thus, we will further define and dissect the specific types of growth constructs and how FP affects these subsets. The hypotheses were tested by SEM, using the input model in AMOS (Analysis for Moments Structures), as shown in Figure 2. The Maximum Likelihood function was used to estimate the model parameters.

\section{The impact of family participation, growth intentions and expansion plans}

Family participation in the business has a positive impact and encourages the entrepreneurial development and expansion. Participation of the family in employment and investment, revealed to be encouraging too. These findings conclude that new emerging family businesses tend to expand and grow which lead to witness a transition from war and foreign occupation to an open market economy.

Six specific growth constructs have been identified and validated in these entrepreneurially led family enterprises. Using AMOS 5.0.1, we obtained the results presented in Table 6. For 
example, the squared multiple correlations (SMC) of 0.526 in $\mathrm{H} 1$ reveal that FP explains $52.6 \%$ of variance in EU. The path coefficient in $\mathrm{H} 1$ is 0.756 . All paths are statistically significant at the 0.001 level.

\begin{tabular}{|l|l|l|l|l|}
\hline Hypothesis & $\begin{array}{l}\text { Testing the relationship } \\
\text { between }\end{array}$ & $\begin{array}{l}\text { Squared } \\
\text { Multiple } \\
\text { correlation }\end{array}$ & $\begin{array}{l}\text { Standardized } \\
\text { regression } \\
\text { coefficient }\end{array}$ & p-value \\
\hline \hline H1 & $\begin{array}{l}\text { FP has a positive impact on } \\
\text { EquipUpg }\end{array}$ & 0.526 & 0.725 & $* * *$ \\
\hline H2 & $\begin{array}{l}\text { FP has a positive impact on } \\
\text { BusDev }\end{array}$ & 0.761 & 0.872 & $* * *$ \\
\hline H3 & $\begin{array}{l}\text { FP has a positive impact on } \\
\text { OpExp }\end{array}$ & 0.484 & 0.695 & $* * *$ \\
\hline H4 & $\begin{array}{l}\text { FP has a positive impact on } \\
\text { ITUpg }\end{array}$ & 0.408 & 0.639 & $* * *$ \\
\hline H5 & $\begin{array}{l}\text { FP has a positive impact on } \\
\text { MktExp }\end{array}$ & 0.508 & 0.713 & $* * *$ \\
\hline H6 & $\begin{array}{l}\text { FP has a positive impact on } \\
\text { MktDev }\end{array}$ & 0.662 & 0.814 & $* * *$ \\
\hline
\end{tabular}

*** denotes $\mathrm{p}<0.001$

Source: Family and Cultural Factors impacting Entrepreneurship in war time Lebanon, (Fahed-Sreih et al, 2010)

Table 6. Summary of the Parameters for the Research Model

\section{So what- practical implications for entrepreneurs and policy makers}

Lebanon represents both unique opportunities and challenges to enterprises large and small. There are many emerging opportunities to work with Lebanese entrepreneurs both at home and abroad. This research provides helpful insights that have sensible applications for entrepreneurs and businesses in general.

\section{Conclusion}

This study was made on a small sample of Lebanese entrepreneurs in a traumatic post-war economy. Although it shows part of the Lebanese society, it provides one remarkable caution and distrust permeating Lebanese society. The insights provided in this research mark a rare and in-depth examination into the engine driving the reconstruction of the postwar economy, with family participation serving as a strong component.

This study highlights the vital need for the Lebanese government to support the Lebanese companies with financial resources, services and create innovative programs. This is critical for the growth of new businesses, as well as the continuity and succession of larger, more established companies. 


\section{References}

Ali, A., (1993). Management theory in a transitional society: The Arab's experience, International Studies of Management and Organization, 20(3), 7-35.

Barakat H. (1977). Lebanon in Strife: Student Prelude to the Civil War, Austin: University of Texas Press.

Bauer, R., (1966). Social Indicators, edited. by R. Bauer, MIT Press, Cambridge, MA, 1966.

Bollen, K. (1989). Structural Equations with Latent Variables. John Wiley, NY, 1989.

Carland, J., Hoy, F., Boulton, W., \& Carland, J. C. (1984) Differentiating Entrepreneurs Small Business Owners: A Conceptualization, Academy of Management Review, 9(2): 7384.

Chicago Tribune, Paralysis grips Lebanon, November 24, 2007, section 1, page 8 The Daily Star, Beirut, Lebanon, April, 2005. The Economist, Freeing the cedars from Western blight, November 4-10, 2006, pp. 51-52.

Diab, L.N. (1980). Postwar group Affiliations of Lebanese Students. The Journal of Social Psychology, 110, 145-146.

Dunkelberg, W., \& Cooper A. (1982) Entrepreneurial Typologies, Frontiers Of Entrepreneurship Research 1982, ed.K. Vesper, Babson College: 1-15.

Fahed-Sreih J., (2004). Facts and Figures Concerning Family Businesses in Lebanon, Franklin Publishing, USA.

Fahed-Sreih, J., (2006). Lebanon, Handbook of Family Business and Family Business Consultation A Global Perspective, International Business Press, Binghamton, NY, 203- 222.

Fahed-Sreih, J., Pistrui, D., Welch, H., Huang, W., (2010), Family and Cultural Factors impacting Entrepreneurship in war time Lebanon", International Journal of Entrepreneurship and Innovation Management 2010,volume 12, No.1 pp. 35-51. Special Issue: Family and Cultural Factors Impacting Entrepreneurship and Innovation.

Faour, M., (1998), "The Silent Revolution in Lebanon: Changing Values of the Youth", Beirut, Lebanon, Lebanese American University of Beirut.

Gefen, D., Straub, D., and Boudreau, M. (2000). Structural equation modeling techniques and regression: guidelines for research practice, Communications of the AIS, 2000, $1(7), 1-78$.

Gundry, L., \& Welsch, H. (2001) "The Ambitious Entrepreneur: Attributes Of Firms Exhibiting High Growth Strategies of Women-Owned Enterprises," Journal of Business Venturing, 16(5): 453-470.

Habbershon, T., \& Pistrui, J. (2002) Enterprising Families Domain: Family-Influenced Ownership Groups in Pursuit of Transgenerational Wealth, Family Business Review, XV (3): 223-237.

Hair, J., Anderson, R., Tatham, R., and Black, W., (1998). Multivariate Data Analysis, Prentice Hall, Upper Saddle River, NJ.

Klaushofer, A. (2006). Lebanon businesses try to bounce back, BBC News, news.bbc.co.uk, /2/hi/middle_east, pp. 1-3.

Melikian, L.H., and Diab, L.N. (1959). Group Affiliation of University Students in the Arab Middle East, The Journal of Social Psychology , 49, 145- 159. 
Melikian, L.H., and Diab, L.N., (1974). Stability and Change in Group Affiliations of University Students in the Arab Middle East, The Journal of Social Psychology, 93, 1321.

Pistrui, D., (2002). Growth Intentions and Expansion Plans of New Entrepreneurs in Transforming Economies: An Investigation Into Family Dynamics, Entrepreneurship and Enterprise Development, Universitat Autonoma de Barcelona, Barcelona, Spain, doctoral dissertation.

Pistrui, D., and DeLucia, D., (1999). Growth Intentions and Expansion Plans Of Venezuelan Entrepreneurs: An Investigation Into Family Dynamics, Entrepreneurship and Enterprise Development, Strategies for the New Millennium, Family Firm Institute 1999 Family Firm Conference Proceedings, Family Firm Institute, Boston, MA, Spring, 151-153.

Pistrui, D., Huang, W., Oksoy, D., Jing, Z., and Welsch, H. (2001). Entrepreneurship in China: characteristics, attributes, and family forces shaping the emerging private sector. Family Business Review, 14 (2), 141-152.

Pistrui, D., Huang, W., Welsch, H., and Jing, Z., (2006). Family and cultural forces: shaping entrepreneurship and SME development in China, Handbook of Research on Family Businesses, Poutziouris, P., Smyrnios, K., and Klein, S., (eds), Edward Elgar, Northampton, MA, USA, 460-487.

Pistrui, D., Welsch, H., \& Roberts, J. (1997). Growth Intentions and Expansion Plans of New Entrepreneurs in the Former Soviet Bloc, Entrepreneurship and SME Research: On its way to the next millennium, Ed. R. Donckels, and A. Miettinen, Ashgate, Aldershot, UK, 93-111.

Pistrui, D., Welsch, H., \& Roberts, J. (1997). The [re]-emergence of family business in the transforming Soviet Bloc. Family Business Review, 10(3), 221-237.

Pistrui, D., Welsch, H., Wintermantel, O., Liao, J., \& Pohl, H. (2003). Entrepreneurship in the New Germany, Small Firms and Economic Development in Developed and Transition Economies: A Reader, edited by D. Kirby, and A. Watson, Ashgate, Andershot, UK, 116-130.

Plamondon, B., (2004), Economics, Middle East and Africa, Global Insight Report, Lebanon, 2004.

Poutziouris, P., O'Sullivan, K., and Nicolescu, L., (1997). The [Re]-Generation of Family Entrepreneurship in the Balkans, Family Business Review, 10(3), 239-262.

Sik, E., and Wellman, B., (1999), Network Capital in Capitalist, Communist and PostCommunist Countries, Networks in the Global Village, Edited by B. Wellman, Westview Press, Boulder CO, 225-254.

Steier, L. (2003) “Unraveling The Familial Sub-Narrative In Entrepreneurship Research," Frontiers of Entrepreneurship Research, Wellesley, MA: Babson College: 258-272.

Tambunan, T. (2000). The performance of small enterprises during economic crisis: Evidence from Indonesia. Journal of Small Business Management, 38(4), 93-101.

The World Factbook. (2007). Central Intelligence Agency, Washington, DC.

Wellman, B., (2001). Networking Guanxi, Social Networks in China: Institutions, Culture, and the Changing Nature of Guanxi, Edited by T. Gold, D. Guthrie, and D. Wank, 200223. 
Welsch H., and Pistrui, D., (1996). Essential Elements in Entrepreneurship Development in South Africa: An Analysis of Affecting Factors, International Council for Small Business, 41st World Conference Proceedings, Stockholm, Sweden, June 16-19, 105127. 


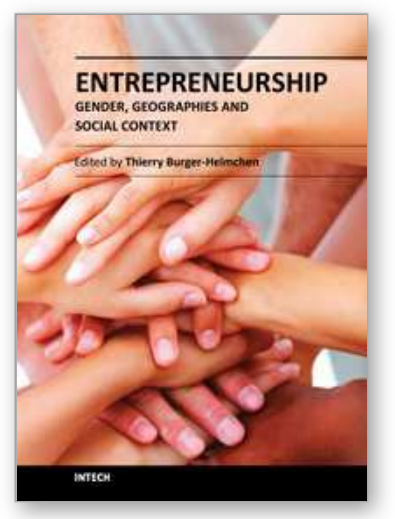

\author{
Entrepreneurship - Gender, Geographies and Social Context \\ Edited by Prof. Thierry Burger-Helmchen
}

ISBN 978-953-51-0206-9

Hard cover, 306 pages

Publisher InTech

Published online 14, March, 2012

Published in print edition March, 2012

Entrepreneurship is a main driver of economic growth and of social dynamics. However, some basic characteristics like the gender of the entrepreneur, the geographical location, or the social context may have a tremendous impact on the possibility to become an entrepreneur, to create a firm and to prosper. This book is a collection of papers written by an array of international authors interested in the question of entrepreneurship from a gender point of view (male vs female entrepreneurship), a geographical point of view (Africa, Europe, America and Latin America, Asia...) or a specific social context point of view (agricultural economy, farming or family business, etc.).

\title{
How to reference
}

In order to correctly reference this scholarly work, feel free to copy and paste the following:

Josiane Fahed-Sreih and David Pistrui (2012). Motives for Entrepreneurship: The Case of Lebanese Family Businesses, Entrepreneurship - Gender, Geographies and Social Context, Prof. Thierry Burger-Helmchen (Ed.), ISBN: 978-953-51-0206-9, InTech, Available from: http://www.intechopen.com/books/entrepreneurshipgender-geographies-and-social-context/motives-for-entrepreneurship-the-case-of-lebanese-family-businesses

\section{INTECH}

open science | open minds

\section{InTech Europe}

University Campus STeP Ri Slavka Krautzeka 83/A 51000 Rijeka, Croatia Phone: +385 (51) 770447 Fax: +385 (51) 686166 www.intechopen.com

\section{InTech China}

Unit 405, Office Block, Hotel Equatorial Shanghai No.65, Yan An Road (West), Shanghai, 200040, China 中国上海市延安西路65号上海国际贵都大饭店办公楼405单元 Phone: +86-21-62489820

Fax: +86-21-62489821 
(C) 2012 The Author(s). Licensee IntechOpen. This is an open access article distributed under the terms of the Creative Commons Attribution 3.0 License, which permits unrestricted use, distribution, and reproduction in any medium, provided the original work is properly cited. 